\title{
Kondycja podmiotu wobec upadku Rzeczypospolitej. Treny Józefa Morelowskiego
}

Treny Józefa Morelowskiego rozpatrywane były najczęściej przez badaczy jako dokument historyczny, świadectwo patriotyzmu wobec klęski III-ego rozbioru ${ }^{1}$. Ten tryb lektury, zwłaszcza w dobie zaborów i późniejszej nadziei na odzyskanie niepodległości, łączył się z dychotomicznym ujęciem relacji między oświeceniem a romantyzmem. W Studium nad „Trenami”, dołączonym do edycji tekstu z 1910 r., Marian Morelowski (ps. Stanisław z Kutnego) zwraca uwage na „szczerość” podmiotu i próbę ominięcia „pseudoklasycznych” reguł, krępujących (rzekomo) ekspresję „Ja" mówiącego ${ }^{2}$. Wskazane w Studium... sposoby wyrażania emocji i środki literackiego obrazowania w przekonaniu Mariana Morelowskiego wydają się jednak oderwane od późnooświeceniowych tendencji literackich oraz ideowych. Można przez to odnieść wrażenie, że upadek Rzeczypospolitej natychmiastowo pociągnął za sobą przeobrażenia o charakterze estetycznym, a nawet mentalnym. I choć piszący pod pseudonimem Stanisław z Kutnego podkreśla obecność tradycji staropolskiej w cyklu Morelowskiego, to - jak twierdzi - pewne fragmenty „mają w sobie coś romantycznego”.

Symptomatyczny jest też komentarz Władysława Włocha, dla którego istotnym kryterium oceny tekstu była „autentyczność” przeżyć narratora. W prze-

\footnotetext{
* mgr Patrycja Bąkowska - Uniwersytet im. Adama Mickiewicza w Poznaniu, Wydział Filologii Polskiej i Klasycznej, Instytut Filologii Polskiej; e-mail: patrycja.bakowska@amu.edu.pl

${ }^{1}$ Zob. E. Aleksandrowska, Wstęp, w: J. Morelowski, Wiersze Józefa Morelowskiego, Wrocław 1983, s. 5-9. Zob. też M. Górowska, Józefa Morelowskiego literackie reakcje na trzeci rozbiór Polski (w kontekście Barda polskiego Adama Jerzego Czartoryskiego). Rekonesans, „Acta Universitatis Lodziensis. Folia Litteraria Polonica" 2013, nr 4(22), s. 27-44.

${ }^{2}$ Stanisław z Kutnego, Studium nad Trenami, w: J. Morelowski, Treny i Sen, Kraków 1910, s. 9-12.

3 Tamże, s. 11.
} 
ciwieństwie jednak do przywołanego wcześniej stanowiska, autor Polskiej elegii patriotycznej w okresie rozbiorów określił Treny mianem „wierszowanego wypracowania szkolnego", rażącego sztucznością, wynikającą ze zbytniego przywiązania do reguł poetyckich ${ }^{4}$.

Mimo oczywistej różnicy, przytoczone opinie zwracają uwagę na istotną kwestię, jaką jest sposób ekspresji „Ja”. Odmienność ocen wynika z faktu, że za punkt wyjścia obrano relację między tzw. pseudoklasycyzmem i romantyzmem, przez co samo oświecenie - prymarny kontekst literacki dla cyklu Morelowskiego - zostało pominięte. Od czasu sformułowania tych opinii w stanie badań nad polskim oświeceniem bardzo wiele się zmieniło. Szczęśliwie rozprawiono się z pojęciem pseudoklasycyzmu ${ }^{5}$, a autorzy prac dotyczących oświecenia w Polsce (by tu wspomnieć chociażby Teresę Kostkiewiczową ${ }^{6}$, Marcina Cieńskiego ${ }^{7}$, Elżbietę Wichrowską ${ }^{8}$ ) zwrócili uwagę na specyfikę ekspresji podmiotu w poezji XVIII wieku, w tym na kształtującą się wówczas nową normę intymności ${ }^{9}$.

Nadal jednak bardzo często Treny postrzega się poza ich estetycznym i ideowym tłem. Niegdyś przez Włocha uznane za utwór „w całym znaczeniu tego słowa literacki" (czyli nie oddający przeżyć podmiotu lirycznego), w opinii Piotra Żbikowskiego (podobnie jak pozostałe analizowane przezeń utwory porozbiorowe) antycypują romantyzm, przypominając Księgi narodu i pielgrzymstwa polskiego Adama Mickiewicza ${ }^{10}$. Traktowanie romantyzmu jako punktu dojścia procesu historycznoliterackiego sprawia, że wiele obserwacji rzeszowskiego badacza ma charakter anachroniczny. W konsekwencji - wbrew zamiarom samego Żbikowskiego - przynosi to stereotypowy, uproszczony obraz przeobrażeń, do jakich doszło u schyłku XVIII w. w polskiej poezji ${ }^{11}$. Równie jednostronny (choć poprowadzony z innej perspektywy) tryb lektury dostrzegamy w monografii Polska elegia oświeceniowa. Dzieje i model gatunku 1740-1815, w której autor odmówił cyklowi Morelowskiego ,jakichkolwiek akcentów emocjonalnych"12.

\footnotetext{
${ }^{4}$ W. Włoch, Polska elegia patriotyczna w epoce rozbiorów, Kraków 1916, s. 51.

${ }_{5}^{5}$ Zob. np. P. Żbikowski, Klasycyzm postanisławowski. Doktryna estetycznoliteracka, Warszawa 1984 (tu zwłaszcza s. 37-44).

${ }^{6}$ Zob. np. T. Kostkiewiczowa, Horyzonty wyobraźni: o języku poezji czasów Oświecenia, Warszawa 1984. Taż, Publiczne, prywatne, intymne - o sposobach rozumienia i miejscu w kulturze w XVIII wieku, w: Publiczne, prywatne, intymne w kulturze XVIII wieku, pod red. tejże, Warszawa 2014.

7 Zob. np. M. Cieński, Literatura polskiego oświecenia wobec tradycji i Europy. Studia, Kraków 2013.

${ }_{8}$ Warto mieć tu na uwadze przede wszystkim uwagi i obserwacje badaczki poczynione przy okazji edycji pism autobiograficznych Antoniego Jana Ostrowskiego. Zob. E. Z. Wichrowska, Twoja śmierć. Początki dziennika intymnego w Polsce na przełomie XVIII i XIX wieku, Warszawa 2012.

${ }^{9}$ Zob. np. Ch. Taylor, Nowoczesne imaginaria społeczne, przeł. A. Puchejda, K. Szymaniak, Kraków 2010; H. Arendt, Kondycja ludzka, przeł. A. Łagodzka, wstęp M. Canovan, Warszawa 2010.

${ }^{10}$ P. Żbikowski, „...bolem śmiertelnym ściśnione mam serce”. Rozpacz oświeconych u źródet romantycznego przełomu w poezji polskiej w latach 1793-1805, Wrocław 1998, s. 220.

${ }_{11}$ Tenże, Klasycyzm postanisławowski, dz. cyt., s. 20-22.

12 R. Doktór, Polska elegia oświeceniowa. Dzieje i model gatunku 1740-1815, Lublin 1999, s. 157.
} 
Cezura roku 1795 dla kultury polskiej, skutecznie od lat eksponowana i trwała w powszechnym dyskursie, często sprawia, że do badań nad danym zjawiskiem podchodzimy obarczeni założeniami rzutującymi na sposób jego ujmowania i rozumienia. Różnicę między klasycyzmem stanisławowskim a porozbiorowym podaje w wątpliwość coraz więcej literaturoznawców, w tym (przywoływany już) Marcin Cieński stawiając pytanie o to, na ile upadek Rzeczypospolitej ma raczej historyczno-patriotyczne, na ile zaś (rzeczywiście) historycznoliterackie znaczenie ${ }^{13}$.

Dlatego też, zasygnalizowany w początkowej części niniejszego szkicu, sposób lektury Trenów jako utworu wyrastającego z oświecenia i będącego pod silnym wpływem tradycji staropolskiej, to próba ukazania jego swoistości na płaszczyźnie sposobów literackiego obrazowania i manifestowania „Ja”. Rozbiory stają się katalizatorem wyrażonego w wierszach kryzysu podmiotu, który - próbując się z nim uporać - uruchamia porządek antyczny i biblijny, dokonując ich twórczej i oryginalnej reinterpretacji.

Cykl Morelowskiego składa się z 13 trenów, zwieńczonych elegią pt. Sen. Już pierwsza lektura uświadamia, jak ogromne znaczenie dla autora miała tradycja staropolska. Typowe dla poezji epok dawnych zabiegi artystyczne dominują w omawianych tekstach - sam wybór trenów przywołuje przecież na myśl poezję biblijną, zwłaszcza zaś Lamentacje Jeremiasza. Znaczenie Pisma Świętego, a obrazowania psalmicznego przede wszystkim, dla literatury polskiej do XVIII wieku to zagadnienie szerokie. W syntetycznym ujęciu tej problematyki, zaproponowanym przez Teresę Kostkiewiczową, na pierwszy plan wysuwają się kwestie translatologiczne (w tym poszukiwanie przez tłumaczy Psałterza na języki wernakularne odpowiednich środków literackiej ekspresji), które łączą się z obrazowaniem psalmicznym, chętnie i często wyzyskiwanym w literaturze staropolskiej i oświecenia. Topika psalmiczna obecna była w rozważaniach nad kondycją człowieka, naznaczonego przemijalnością i nieustannie narażonego na niebezpieczeństwo w świecie pełnym zła i grzechu. Interesujące (z perspektywy podejmowanego w niniejszym szkicu tematu) jest też to, że inspiracje psałterzowe (i szerzej - biblijne) odnaleźć można w utworach wyrastających z poczucia zagrożenia odczuwanego czy doświadczanego nie przez jednostkę, ale wspólnotę, by przywołać - jako exemplum - Psalmodię polską Wespazjana Kochowskiego ${ }^{14}$.

${ }_{13}$ M. Cieński, Literatura polskiego oświecenia wobec tradycji i Europy..., dz. cyt., s. 84.

14 T. Kostkiewiczowa, Inspiracje psałterzowe wyobraźni poetyckiej epok dawnych (rekonesans), w: Księga psalmów. Modlitwa, przekład, inspiracja, pod red. P. Mitznera, Warszawa 2007, s. 85-103. Zob. też M. Eustachiewicz, „Psalmodia polska” W. Kochowskiego na tle staropolskich stylizacji biblijnych, „Pamiętnik Literacki” 1974, z. 2, J. Gruchała, „Psalmy, hymny, Pieśnie pełne ducha.” Studia o staropolskich tekstach religijnych, Kraków 2011. 
W tym miejscu warto też podkreślić szczególną rolę Pisma Świętego w tekstach związanych z konfederacją barską i rozbiorami. Przekładu Psalmów pokutnych podjąl się uwięziony przez Rosjan w $1767 \mathrm{r}$. Wacław Rzewuski ${ }^{15}$, natomiast teksty okolicznościowe powstałe w latach 1767-1772 wielokrotnie poddawane były biblijnej stylizacji ${ }^{16}$ (wystarczy wspomnieć chociażby takie utwory, jak: Lament ojczyzny nad wziętymi synami, Lament Wolności i Wiary, Wiersze na imieniny Jego Mości Pana Zamoyskiego przeszłego kanclerza wielkiego koronnego z tych słów Ewangeliji: „Faciam vos piscatorem hominum” czy pieśni poświęcone Maryi ${ }^{17}$ ).

Jedną z istotnych przyczyn popularności Księgi Psalmów, jako źródła wzorców literackiego tworzenia, jest uniwersalny wymiar utworów biblijnych, które mogą służyć jako „formularze do wyrażania relatywnie zmiennych, indywidualnych skarg" ze względu na to, iż opisy cierpienia i prześladowania nie tyle są źródłem konkretnych informacji o prześladowcy czy prześladowanym, ile wyrazem uczuć i doznań ofiary ${ }^{18}$.

Wydaje się, że wskazane tu obserwacje Paula Ricouera możemy zastosować również do wytłumaczenia funkcji trenu w literaturach epok dawnych. Morelowski, wykorzystując ten gatunek, odwołał się do długiej i nadal żywej w XVIII w. tradycji poetyckiej, usankcjonowanej Żalami Owidiusza, (wspomnianymi) Lamentacjami Jeremiasza czy wreszcie - Trenami Kochanowskiego ${ }^{19}$. Na obecność czarnoleskiej tradycji w omawianym tu cyklu zwrócił uwagę Władysław Włoch, wskazując zwłaszcza na kompozycję Trenów Morelowskiego, w której da się zaobserwować swoistą trójdzielność (podobnie jak w wierszach tematyzujących rozpacz ojca po śmierci dziecka), determinowaną przez uczucia i emocje podmiotu lirycznego, takie jak: smutek, zwątpienie i poszukiwanie pociechy ${ }^{20}$. Tropem tym podąża w swojej lekturze Łukasz Słaby, który także eksponuje cechy wspólne porównywanych utworów, związanych głównie z wyrażanymi przez „Ja" liryczne doznaniami ${ }^{21}$.

${ }_{15}$ Pisze o tym m.in. D. Grabowska, Twórczość kałuska Wacława Rzewuskiego, „Zeszyty Naukowe Wydziału Humanistycznego Uniwersytetu Gdańskiego. Prace Historycznoliterackie”, 1985, z. 8-9.

${ }^{16}$ Zob. np. S. Dubisz, Modlitewno-religijne incipity utworów wierszowanych okresu konfederacji barskiej, „Poradnik Językowy” 1996, z. 9.

${ }_{17}$ Zob. Literatura konfederacji barskiej, tom 3: Wiersze, opr. J. Maciejewski i in., Warszawa 2008.

${ }_{18}$ P. Ricouer, Skarga jako modlitwa, w: A. LaCocque, tegoż, Myśleć biblijnie, przeł. E. Mukoid, M. Tarnowska, Kraków 2003, s. 286-306.

19 Jak powszechnie wiadomo, obok określenia „tren” stosowano również inne nazwy, jak „nenia”, "lamentacje” czy „elegie”. Zob. na ten temat J. Pelc, Tren, w: Stownik Literatury Staropolskiej, pod red. T. Michałowskiej, Wrocław 1990, s. 874-877.

${ }^{20}$ W. Włoch, dz. cyt., s. 44-52. O znaczeniu Jana Kochanowskiego dla poezji oświecenia pisał Tomasz Chachulski. Zob. tegoż, Opóźnione pokolenie: studia o recepcji „głębokiej” Jana Kochanowskiego w poezji polskiej XVIII wieku, Warszawa 2006.

${ }^{21}$ Ł. Słaby, „Poezja i wojna. Twórczość poetów-żołnierzy lat 1805-1835 (między legionami a powstaniem listopadowym)"; (korzystałam z niepublikowanej pracy doktorskiej dostępnej w Repozytorium Uniwersytetu im. Adama Mickiewicza w Poznaniu). Wpływ renesansu na poezję Morelow- 
Już w pierwszej strofie Trenu I dostrzegamy oczywiste nawiązanie do utworu Jana z Czarnolasu (Tren I), co pozwala oddać totalny wymiar tragedii, jaka dotknęła podmiot liryczny:

\author{
Wszystkie, niestety polskie razem zorze \\ Zapadły na dno w przepaściste morze! \\ Polak pod Orła i Pogoni znakiem \\ Raz dziś ostatni ze snu wstał Polakiem \\ $(\text { Tren I, s. 31) })^{22}$
}

Do opisu zniszczenia i zagłady państwa wykorzystano, co charakterystyczne dla staropolszczyzny, motywy heraldyczne ${ }^{23}$. Polski Orzeł i litewska Pogoń to, jak powszechnie wiadomo, herb Rzeczypospolitej Obojga Narodów, symbol jedności i równości obywateli. Wspomniane w drugiej strofie „Straszydła czarne, skrzydlate, dwugłowe" (Tren I, s. 31), oczywiste odwołanie do herbu I Rzeszy i Rosji, oddają tragiczne konsekwencje rozbiorów, ukazując znaczenie bytu państwowego dla tożsamości, w jej wymiarze zbiorowym oraz indywidualnym. Oto bowiem podmiot został pozbawiony ojczyzny, skazany na wieczną i bezcelową tułaczkę.

Jako się rzekło, dominantą Trenów jest doświadczenie utraty. Owo doznanie sprawia, że fundujące podmiot strategie (by wspomnieć m.in. wywiedzione z sarmatyzmu konstytuowanie "Ja" w oparciu o dzieje narodu) okazują się niewystarczające i nieadekwatne. W Trenie IX Do Obrońców ojczyzny uchylone zostają, istotne dla obywateli Rzeczypospolitej, ideały osobowe. Niegdysiejszy „obrońca ojczyzny” to dziś „świetny jeniec”. W określeniu tym daje o sobie znać, obecny już w mentalności konfederatów barskich (vide pamiętnik Karola Lubicz-Chojeckiego ${ }^{24}$ ), a szczególnie istotny po roku 1795 (vide wiersze więzienne

skiego podkreśla też Agnieszka Ochenkowska, zob. tejże, Echa tradycji renesansowej w wybranych pieśniach Józefa Morelowskiego, „Ogród Nauk i Sztuk” 2015(5), s. 456-465 (artykuł dostępny na stronie http://www.ogrodynauk.pl/doi/10-15503-onis2015-456-465/).

${ }_{22}$ J. Morelowski, Treny, w: tegoż, Wiersze Józefa Morelowskiego, wstęp i oprac. E. Aleksandrowska, Wrocław 1983, s. 31. Fragmenty wierszy cy towane z tego wydania sygnalizowane będą w następujący sposób (tytuł utworu, strona).

${ }^{23}$ Symbolika heraldyczna w literaturze staropolskiej wiązała się z popularnością emblematów. Za przykład posłużyć może Psalmodia polska Wespazjana Kochowskiego, oparta na konstrukcjach emblematycznych, które w podręcznikach do retoryki były zalecane ze względu na ich walor perswazyjny. J. Pelc, Obraz - słowo - znak. Studium o emblematach w literaturze staropolskiej, Wrocław 1973. Zob. też H. Dziechcińska, Sztuka przekonywania w kulturze polskiej trzech stuleci: XVI - XVII - XVIII wiek, Warszawa 2010.

${ }^{24}$ K. Lubicz-Chojecki, Pamięć dzieł polskich. Podróż i niepomyślny sukces Polaków, oprac. W. Turek, Gdańsk 1992. Pamiętnikom zesłańców syberyjskich poświęciła monografię Agata Roćko, zob. Pamiętniki polskich zesłańców na Syberię w XVIII wieku, Olsztyn 2001. 
Hugona Kołłątaja ${ }^{25} \mathrm{i}$ Juliana Ursyna Niemcewicza ${ }^{26}$ ) nowy wzorzec parenetyczny - więźnia, tułacza ${ }^{27}$.

Dramatyczność tej kondycji oddaje dwukrotnie powtórzony w Trenie I dystych, początkowo - w formie pytania („Mamli narzekać w dzień i w nocy z płaczem,/ Żem został w ziemi mej tułaczem?"), które w końcowej strofie zyskuje już postać twierdzenia („Tylko narzekać w dzień i w nocy z płaczem,/ Żem został w ziemi mej tułaczem"; s. 32, podkreślenia - P.B.). Pozornie tylko nieistotna zmiana odzwierciedla pogłębiającą się rozpacz osoby mówiącej, zwłaszcza zaś dojmujące poczucie bezsilności i brak nadziei, co wzmaga wspomnienie (nie tak odległej jeszcze) potęgi Rzeczypospolitej. „Ja” liryczne, podobnie jak biblijni psalmiści opłakujący zniszczenie Jerozolimy, rozpaczy pokonanych przeciwstawia śmiech i drwiny wrogów (zob. zwłaszcza Lamentacje Jeremiasza), przywołując również obecną w Trenach Jana Kochanowskiego polemikę ze stoickim rozumieniem cnoty.

Odwołanie do wskazanych fragmentów Starego Testamentu czy literatury staropolskiej to próba oddania na płaszczyźnie literackiej traumatycznego doświadczenia cierpienia, za którym stoi poczucie bezcelowości (podmiot wszak sam siebie nazywa tułaczem). Destrukcyjne dla „Ja” konsekwencje upadku państwa wiążą się z zakorzenionym w sarmatyzmie przekonaniem o ścisłej więzi między Rzeczpospolitą a jej obywatelami, dlatego - wezwane w Trenie II „przodków cienie”- wypowiadają następujące słowa: „Był naród, była Polska, byliśmy Polacy" (Tren II, s. 33). Pytanie o możliwość istnienia narodu mimo braku państwa to kwestia (zwłaszcza po 1795 r.) fundamentalna. Wraz z kolejnymi klęskami zrywów narodowo-niepodległościowych coraz większą popularność zyskiwały koncepcje, zgodnie z którymi gwarantem tożsamości narodowej były kultura i tradycja. W Trenie II próżno jednak dopatrywać się (już) tego typu myślenia. Trzykrotne powtórzenie czasownika „był” oddaje rozpacz Polaków pozbawionych państwa, tu rozumianego nie tyle w jego wymiarze politycznym, co przede wszystkim ideowym. Upadek Rzeczypospolitej przekreśla zatem możliwość bycia Polakiem, staje się traumatycznym i dezintegrującym „Ja" doznaniem.

${ }^{25}$ P. Żbikowski, Poezje więzienne Hugona Kołłątaja. Studia i teksty, Wrocław 1993.

${ }^{26}$ J. U. Niemcewicz, Smutki [...] w więzieniu moskiewskim pisane do przyjaciela, z rkp. wyd. L. Kamykowski, Lublin 1932; tegoż, Ostatnie rymy [...] pod tytułem „Treny wygnańca”, Lipsk 1833.

${ }^{27}$ Cenne rozpoznania w tym temacie poczynili zresztą: Janina Kamionka-Straszakowa (Zabłakany wędrowiec. Z dziejów romantycznej topiki, Wrocław 1992), Marcin Chrostek (Etos dziewiętnastowiecznych zesłańców, Wrocław 2008), Marcin Cieński (Karpiński wobec doświadczenia wygnania: biografia i kreacja literacka, w: tegoż, Literatura polskiego..., dz. cyt., Kraków 2013) czy Jerzy Borowczyk (Zesłane pokolenie. Filomaci w Rosji (1824 - 1870), Poznań 2014). Zob. też artykuły zamieszczone w tomie pokonferencyjnym Emigranci, wygnańcy, wychodźcy..., pod red. I. Węgrzyn i G. Zająca, Kraków 2007. 
Warto przypomnieć, że przywołane wcześniej sformułowanie „Był naród, była Polska..." jest (czytelnym zwłaszcza dla odbiorcy w XVIII w.) odwołaniem do Eneid ${ }^{28}$. O znaczeniu Wergiliusza dla Polaków w okresie rozbiorów wspominał Ignacy Chrzanowski ${ }^{29}$, nawiązując do obecnego wówczas w mentalności Polaków przekonania o podobieństwie losu Troi i Polski. Znajduje to też swoje odzwierciedlenie w poezji Jana Pawła Woronicza, dla którego analogia Polska-Troja miała przede wszystkim charakter kompensacyjny, który najwyraziściej oddaje wers z Świątyni Sybilli „Troja na to upadła, aby Rzym zrodziła” ${ }^{30}$.

Jak sygnalizowano, kompozycję cyklu wyznacza doświadczenie utraty. Symbolizuje je wspomniane nacechowane aksjologicznie zestawienie białego orła i „czarnych, dwugłowych straszydeł” czy mapa Królestwa Polskiego, na której „łzy [...] rzęsiste/ Piszą [...] trzech wrogów granice troiste” (Tren III, s. 34). Tren III, z którego pochodzą przywołane wersy, nosi znamienny podtytuł $\mathrm{Na}$ widok mapy królestwa Polskiego. Osoba mówiąca postrzega wspominane przez siebie miejsca przez pryzmat związanych z nimi emocji i - przede wszystkim - rozgrywających się w nich wydarzeń, kluczowych w dziejach Polski. Staje się to kolejny raz (vide Tren I) okazją do podkreślenia rozziewu między przeszłością a teraźniejszością: „Każde miasto pomnikiem było polskiej chwały,/ Dziś szyderstwem, dziś łupem trzech sępów zostały” (Tren III, s. 35).

$\mathrm{W}$ tym kontekście na uwagę zasługuje fragment Trenu $I V$, skierowanego Do dziejów polskich:

\footnotetext{
Mogęż was, zgasły Polak, zwać dziejami memi, Gdy Polski, Gdy Polaków nie ma w polskiej ziemi? Rycerzów niegdyś naszych, królów czyny sławne Nie są to więcej moje, są to dzieje dawne.
}

(Tren IV, s. 36; podkreślenie - P.B.)

Opozycja „moje” - „dawne” oddaje poczucie wydziedziczenia z historii, jednego $\mathrm{z}$ wielu fundamentów sarmatyzmu ${ }^{31}$, którego tradycja $\mathrm{w}$ dobie poroz-

${ }^{28}$ Zob. też M. Janion, M. Żmigrodzka, Romantyzm i historia, Gdańsk 2001, s. 63.

${ }^{29}$ I. Chrzanowski, Czym był Wirgiliusz dla Polaków po utracie niepodległości, w: tegoż, Optymizm i pesymizm polski. Studia z historii kultury, wyboru dokonał A. Biernacki, Warszawa 1971. Zob. też M. Klimowicz, „Exoriare aliquis nostris ex ossibus ultor” w literaturze i historii polskiej, „Pamiętnik Literacki” 1972, z. 1, s. 57-80.

${ }^{30}$ J. P. Woronicz, Świątynia Sybilli, w: Pisma wybrane, wstęp i oprac. M. Nesteruk, Z. Rejman, Warszawa 1993, s. 205.

${ }^{31}$ Szczegółowo o tym zagadnieniu pisała M. Falińska, Przeszłość a teraźniejszość. Studium z dziejów świadomości historycznej społeczeństwa staropolskiego, Warszawa 1986. Zob. też, K. Bartkiewicz, Obraz dziejów ojczystych w świadomości historycznej w Polsce doby oświecenia, Warszawa 1979. 
biorowej była ciągle żywa. Przywiązanie szlachty do dziejów, w szczególności zaś pamięć o zwycięskich bitwach i ich wodzach, pełniło funkcję więziotwórczą w wielonarodowej i wielowyznaniowej I Rzeczypospolitej. Co istotne, dla społeczności szlacheckiej dzieje dawne były ważne w procesie konstruowania tożsamości rodowej. Pozytywnie waloryzowana "dawność" sankcjonowała i umacniała pozycję szlachty jako stanu panującego ${ }^{32}$. Ponadto - wbrew obiegowej opinii o ahistoryczności oświecenia - w XVIII w. coraz większą popularność wśród myślicieli zyskiwało ujmowanie historii jako siły kształtującej człowieka ${ }^{33}$.

Tego typu sposoby konstytuowania „Ja" znajdują się niejako poza zasięgiem podmiotu lirycznego, dlatego też doświadczenie wykorzenienia ma charakter totalny. Zaproponowany tryb lektury uzasadnia Tren V. Do Muz polskich. Polakowi, pozbawionemu państwa, zostaje ostatecznie zabrana „ojczysta mowa” i poezja ${ }^{34}$ :

Gdy z czasem, zapomniawszy swej ojczystej mowy,

Litwin zmięsza swe polskie z moskiewskimi słowy,

A Polak, co w niemieckich dziś pętach rozpacza,

Na Skargów, na Krasickich nie znajdzie tłumacza.

(Tren $V$, s. 37)

Nie ulega wątpliwości, że wydarzenia z roku 1795 obudziły w świadomości wielu głębokie przeświadczenie o znaczeniu literatury rodzimej dla zachowania poczucia odrębności i tożsamości narodowej. Należy przy tym pamiętać, że to właśnie na wiek oświecenia przypada szczególne zainteresowanie językami narodowymi ${ }^{35}$. Jak podkreśla Zofia Florczak, europejskie teorie językowe na początku XVIII stulecia koncentrowały się wokół zagadnienia uniwersalnych cech mowy, czemu podporządkowane były gramatyki narodowe. Schyłek wieku przyniósł zmianę, a problematyka gramatyki uniwersalnej ustąpiła pod wpływem coraz silniejszego przekonania o tym, iż język odzwierciedla charakter danego narodu, stąd też poszukiwano wyróżników swoistości i oryginalności poszczególnych

32 A. F. Grabski, Myśl historyczna polskiego oświecenia, Warszawa 1976, s. 24.

33 Tamże, s. 59.

${ }^{34}$ Jak wskazuje zresztą Teresa Kostkiewiczowa, troska o język polski, czy raczej lęk przed jego zanikiem był w dobie porozbiorowej powszechnym zjawiskiem. Zob. Taż, Horyzonty wyobraźni..., dz. cyt., s. 250-251.

${ }^{35}$ Wypada jednak mieć na uwadze, że kwestia ta pojawiała się i w dobie przedrozbiorowej. Tzw. „walka o język" - korzystając ze sformułowania i rozpoznań Marii Renaty Mayenowej czy Barbary Otwinowskiej- była efektem rodzącej się w XV wieku świadomości narodowej, czemu towarzyszyło rosnące poczucie kulturowej, mentalnej odrębności. M. R. Mayenowa, Wstęp, w: Walka o język $w \dot{z} y c i u$ i literaturze staropolskiej, bibliografię oprac. B. Otwinowska, L. Pszczołowska, J. Puzynina, wyd. 2, Warszawa 1955, s. 7. 
języków ${ }^{36}$. Warto jednak zwrócić uwagę, że to przekonanie, głównie kojarzone z Herderem, na gruncie polskim istniało niejako niezależnie. Ewa Zielaskowska, analizując $O$ rymotwórstwie i rymotwórcach Ignacego Krasickiego, dostrzega, że zawarte tam uwagi poczynione na marginesie lektury Pieśni Osjana świadczą o nowożytnickich poglądach XBW ${ }^{37}$. Widzimy zatem, że myślenie, które powszechnie uznaje się za typowo romantyczne, nieobce było oświeconym, co kolejny raz podaje $\mathrm{w}$ wątpliwość użyteczność i adekwatność kategorii przełomu oświeceniowo-romantycznego do badania literatury i kultury schyłku XVIII i początku XIX w.

Ponadto, jako się rzekło, w sygnalizowanym wyżej okresie przekonanie o szczególnym znaczeniu kultury dla narodu pozbawionego państwa było powszechne ${ }^{38}$. Możemy odnaleźć je chociażby w utworach Jana Pawła Woronicza, by przywołać np.: Pierwszy rys poematu epicznego pod tytułem „Jagielloniada” w XXIV pieśniach, Głowa Jana Kochanowskiego ${ }^{39}$. Znamienne jest, że przywołany tu tekst (tj. Głowa Jana Kochanowskiego) został poprzedzony mottem zawierającym fragment z dedykacji Psałterza Dawidów w przekładzie poety z Czarnolasu. Podkreśla to, iż fakt przełożenia Psalmów na język polski jest wkroczeniem na nieznany dotychczas w narodowej poezji obszar.

Ogromny szacunek wobec Kochanowskiego wynika z tego, iż podejmując się trudu tłumaczenia Psalmów, umożliwiając tym samym Polakom śpiewanie ich w ojczystym języku, poeta niejako „zbliżył” rodaków do Boga. Woronicz podkreśla rolę psalmów pochwalnych, pamiętając przy tym o ich funkcji pocieszycielskiej - wiara w dobrego Boga, opiekuna ludzkości jest przecież głównym punktem historiozofii autora Świątyni Sybilli, którego projekt kultury polskiej powstał w odpowiedzi na rozbiory (stąd też akcentowanie funkcji integrującej, jaką literatura miała pełnić dla społeczności pozbawionej państwa). Podobne dowartościowanie sztuki słowa dostrzec można też w pismach Kazimierza Brodzińskiego. Literatura przedstawiana jest w nich nie tylko jako narzędzie

${ }^{36}$ Z. Florczak, Europejskie źródła teorii językowych w Polsce na przełomie XVIII i XIX wieku. Studia $z$ dziejów teorii języka i gramatyki, Wrocław 1978, s. 107-118. Wyrazistym przejawem wzrastającego zainteresowania językiem polskim były badania prowadzone w ramach Towarzystwa Warszawskiego Przyjaciół Nauk. Zob. H. Jurkowska, Pamięć sentymentalna. Praktyki pamięci w kręgu Towarzystwa Warszawskiego Przyjaciół Nauk i w Puławach Izabeli Czartoryskiej, Warszawa 2014, s. 101.

${ }^{37}$ E. Zielaskowska, „Eącząc kunszta z natura” czyli Ignacego Krasickiego teoria poezji, w: tejże, O rymotwórstwie i rymotwórcach. Ignacy Krasicki między starożytnikami i nowożytnikami, Poznań 2014, s. 139.

${ }^{38}$ Zob. np. H. Jurkowska, Pamięć sentymentalna..., dz. cyt., s. 90-91.

${ }^{39}$ Wypada mieć w pamięci fakt, że Głowa Jana Kochanowskiego, uznana za tekst Woronicza i jako taka funkcjonująca w zbiorowym wydaniu jego pism pod red. Małgorzaty Nesteruk i Zofii Rejman, bywa też przypisywana Franciszkowi Morawskiemu. Zob. np. A. Aleksandrowicz, Wprowadzenie do lektury, [w:] Opisy niektórych pamiątek zachowanych w Światyni Sybilli w Puławach, oprac. taż i A. Timofiejw, Warszawa 2010, s. 12. Zob. J. P. Woronicz, Pisma wybrane, dz. cyt. 
dydaktyczne, ale przede wszystkim jako fundamentalny czynnik umacniający więzi narodowe i kształtujący poczucie przynależności do określonej wspólnoty, zdeterminowanej kulturą i tradycją ${ }^{40}$.

Upadek Rzeczypospolitej uchyla w podmiocie lirycznym Trenów Morelowskiego przekonanie o teleologicznym wymiarze procesu dziejowego. Jednocześnie w wypowiadanych przezeń słowach dostrzegamy tęsknotę za nie tak odległym przecież jeszcze porządkiem, co uwypukla upersonifikowanie w Trenie VII „niewinności” i „sprawiedliwości”, uznanych za podstawę ładu na świecie: „Bez was świat stać nie może: zgubi jędza wściekła/ Naród ludzki, a ziemia weźmie postać piekła" (Tren VII, s. 40). W konsekwencji, jak można wyczytać z przywołanego wiersza, ukaranie odpowiedzialnych za cierpienia Polaków jest niezbędne, by przywrócić harmonię i spokój. Odwołanie się do pojęć niewinności i sprawiedliwości, których sposoby definiowania różnią się w zależności od ujęcia (by wskazać chociażby ujęcie klasyczne czy katolickie), egzemplifikuje wcześniej wspomniane zagubienie podmiotu. Mając na uwadze obecność wątków mitologicznych w poezji epok dawnych ${ }^{41}$, Morelowski wyzyskuje skonwencjonalizowany chwyt literacki, by tym bardziej podkreślić tragizm sytuacji „Ja” lirycznego. Jawna niesprawiedliwość - złamanie zasady organizującej życie człowieka - niesie za sobą poważne skutki. Wizja zagłady rodzaju ludzkiego i opanowania ziemi przez zło to zapowiedź powrotu do chaosu, z którego kiedyś wyłonił się świat.

W cyklu Morelowskiego bardzo często pojawiają się apostrofy do hipostazowanych pojęć, nasuwających skojarzenie z porządkiem mitologicznym. Za przykład posłużyć mogą Tren VII, Tren XI. Do Czasu, czy Tren X:

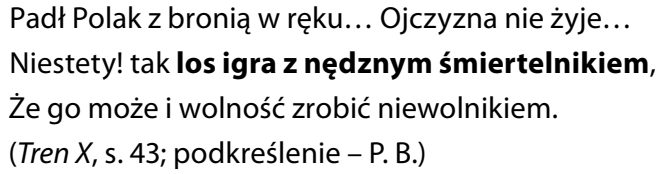

Sugestywnie nakreślony obraz ludzkiej kondycji naznaczonej przypadkowością, uwarunkowanej zmiennymi wyrokami fortuny, wydaje się nieoczywisty czy raczej niekonsekwentny, jeśli wziąć pod uwagę całość wiersza. Wspomniana dwukrotnie „Boska kara” w żaden sposób nie łączy się z losem. Nie mamy tu do czynienia z typowym dla neostoicyzmu podporządkowaniem fortuny Bożej Opatrz-

${ }^{40}$ I. Bittner, Brodziński - historiozof, Wrocław 1981, s. 66-67.

${ }^{41}$ Zob. np. J. Budzyński, Horacjanizm w liryce polsko-łacińskiej renesansu i baroku, Wrocław 1985, J. Brzozowski, Muzy w poezji polskiej: dzieje toposu do przełomu romantycznego, Wrocław 1986. 
ności bądź tylko i wyłącznie z charakterystycznym w epokach dawnych toposem literackim ${ }^{42}$. Obecność dwóch porządków - antycznego i judeochrześcijańskiego - kolejny raz oddaje zagubienie podmiotu lirycznego i rozczarowanie wywiedzionymi z różnych kultur narracjami, regulującymi prawa i zasady rządzące światem.

W przywołanym fragmencie na uwagę zasługuje też motyw wolności. Jej nadużywanie, piętnowane częstokroć w literaturze staropolskiej i oświecenia (by wspomnieć chociażby O poprawie Rzeczypospolitej Andrzeja Frycza Modrzewskiego), staje się tu (podobnie jak w wielu utworach tematyzujących klęskę roku 1795) przyczyną upadku Rzeczypospolitej. Jednocześnie wpisana w model republikański wolność to warunek sine qua non bycia Polakiem. Konsekwencją jej utraty jest niemożność samorealizacji, pełnienia obowiązków (ale i korzystania z przywilejów) dotychczas definiujących i determinujących tożsamość. Przeświadczenie, że wolność jest immanentną cechą Polaków, powszechne było zarówno w wieku XVI, jak i XVIII (chociaż sposób jej definiowania podlegał zmianom) ${ }^{43}$. Owe przeobrażenia prześledziła Anna Grześkowiak-Krwawicz i choć kwestie podejmowane przez badaczkę wykraczają poza podejmowaną tu tematykę, to warto podkreślić, że wśród oświeconych (niezależnie od opcji politycznej) panowało „przekonanie o pradawnym istnieniu wolności polskiej”44.

Spośród trzynastu trenów, tylko w trzech obserwujemy odwołania do Boga chrześcijan ${ }^{45}$. W Trenie I oraz w Trenie $X$ Stwórca przywoływany jest w kontekście kary (wymierzonej w przeciwników bądź samych Polaków, odpowiedzialnych za zagładę ojczyzny). Dopiero w Trenie XIII Bóg ukazany został jako opiekun, Najwyższa Istota, w której wierni pokładają nadzieję:

\author{
Boże! wszak nasi przodkowie o Tobie \\ Nam powiadali, żeś zawsze w złej dobie \\ Bronił niewinnych; a co ich gnębili, \\ Sami tyrani pęta ich nosili.
}

(Tren XIII. Do Boga, s. 45)

${ }^{42} \mathrm{O}$ sposobach konceptualizowania kategorii fortuny, losu, przypadku w literaturze epok dawnych zob. np. J. Sokolski, Bogini, pojęcie, demon. Fortuna $w$ dziełach autorów staropolskich, Wrocław 1996; E. Lasocińska, „Cnota sama z mądrościa jest naszym żywotem”. Stoickie pojęcie cnoty w poezji polskiej XVII wieku, Warszawa 2003.

${ }^{43}$ Na płaszczyźnie literackiej świetnym tego przykładem jest (wspominana) już Psalmodia polska Wespazjana Kochowskiego. Zob. np. K. Obremski, Sarmacki mesjanizm, „Ogród” 1994, nr 4, s. 119-130

${ }^{44}$ A. Grześkowiak-Krwawicz, Regina libertas. Wolność w polskiej myśli politycznej XVIII wieku, Gdańsk 2006, s. 54.

${ }^{45}$ Osobną kwestią jest wieńczący cykl utwór Sen, do którego odwołam się w dalszej części niniejszego szkicu. 
Szczególnie interesujący wydaje się fakt, że wiersze bezpośrednio poprzedzające Tren XIII poświęcone były nadziei (Tren XII) i czasowi (Tren XI). Ten porządek sugeruje, by cykl Morelowskiego czytać jako proces poszukiwania transcendencji, nadrzędnej mocy sterującej i porządkującej świat ludzki. Jest to zresztą konsekwencja wskazywanej już wcześniej kondycji podmiotu lirycznego, pozbawionego przecież państwa, wydziedziczonego z historii, skazanego na los tułacza.

"Ja" liryczne testuje różnorodne, usankcjonowane kulturą i tradycją narracje, które stanowią swoiste strategie ponownego zakorzenienia, zakotwiczenia w bycie. Próżno doszukiwać się tu jakichkolwiek tonów oskarżycielskich wobec Boga czy próby scedowania nań odpowiedzialności za istnienie zła oraz niesprawiedliwości. Zaś błagalny charakter Trenu XIII sprawia, że zwrot do Stwórcy wyrażający poczucie rozpaczy, jest też dowodem silnej i niesłabnącej wiary:

\section{Powstań, o Boże! karz wrogi złośliwe, \\ Zapal w Twych chmurach pioruny gniewliwe! \\ Niech się car hardy gromów Twych ulęknie}

I nasz hołdownik znów przed nami klęknie.

(Tren XIII. Do Boga, s. 45; podkreślenie - P.B.)

Prośba o ukaranie przeciwników przypomina psalmy biblijne (np. $\operatorname{Lm} 3$, 64-66). Historia, jako płaszczyzna przejawiania się wyroków Jahwe, stanowiła dla Żydów potwierdzenie zawartego ze Stwórcą przymierza. Analogiczny sposób myślenia dostrzegamy w sarmackim mesjanizmie, którego echa odnajdujemy w poezji porozbiorowej. Podkreślony wers wyraża nadzieję podmiotu na odbudowanie relacji z Bogiem i przywrócenie dawnej świetności Rzeczypospolitej ${ }^{46}$. Zwieńczenie cyklu stanowi Sen, „zapowiadany” przez poprzedzające go wiersze. Podobnie jak w Trenie II, tak i tutaj pojawiają się najważniejsze postaci z dziejów I Rzeczypospolitej; z Trenu VII „wzięto” motyw niewinności i niezasłużonego cierpienia, zaś topos lutni wykorzystano w Trenie Vi Trenie VIII. Owych nawiązań można by wskazać więcej, ale już te podkreślone uzasadniają lekturę utworu Morelowskiego jako exemplum sposobu oswajania świata i próby wyeliminowania zeń zła bezcelowego. Poszczególne treny stanowią etapy drogi do Boga - Boga Polaków, Pana Historii, który wskrzesi ojczyznę.

Pozytywny ton wiersza zamykającego cykl nie słabnie, nawet jeśli wziąć pod uwagę, że jest to - zgodnie z tytułem - sen. Zakorzenione w kulturze przeświadczenie o profetycznym wymiarze marzeń sennych przynosi nadzieję, dzięki której podmiot wypowiada te słowa:

${ }^{46}$ Musimy bowiem pamiętać, że w Trenach, mimo ukazania Rzeczypospolitej jako ofiary Rosji, Prus i Austrii, pojawiają się jednak sugestie, że to sami Polacy ponoszą odpowiedzialność za zniszczenie państwa. Zob. Tren XIII. Do Boga: „A chociaż słusznie skarałeś za winy/ Nas, od swych ojców mniej cnotliwe syny". 
Lutnio! com cię miał złożyć na ojczyzny grobie, Zostań przy mnie. Łaskawe niebo zdarzy tobie Może dożyć tych czasów szczęśliwych na ziemi I witać nową Polskę pieśni weselszemi.

(Sen, s. 53)

Podjęta $\mathrm{w}$ przedstawionym utworze próba uporania się $\mathrm{z}$ doświadczeniem zła sprawiła, że obecne już w Księdze Hioba pytanie o przyczynę cierpień niewinnych ludzi zostało ponowione. W Trenach Józefa Morelowskiego, pisanych zgodnie z układem cyklu funeralnego, można by wydzielić część pochwalną, lamentacyjną i konsolacyjną. Wspomnienie dawnych dziejów i wybitnych wodzów oraz władców Rzeczypospolitej ukazuje rozziew między przeszłością i teraźniejszością opisywaną, ale też doświadczaną przez osobę mówiącą. Ponadto właśnie wizja tego, co minione, wzmaga w podmiocie omawianego cyklu poczucie utraty i alienacji. Kiedyś obywatel wolnej Polski, potomek walecznych sarmatów, następstwa rozbiorów odbiera jako przerwanie ciągłości historii i tradycji, stanowiących przecież fundament jego tożsamości i umożliwiających samookreślenie.

Nadzieję na zmianę przynosi jednak (zakotwiczona w sarmackim mesjanizmie) wiara w szczególną opiekę Stwórcy nad Polakami, dlatego poruszona w Trenach kwestia teleologicznego wymiaru ludzkiej egzystencji zostaje uzupełniona przez wizję odrodzenia Rzeczypospolitej i przywrócenia dawnego ładu. Zagubienie podmiotu jest niejako wpisane w samą naturę wiary. Doświadczenie cierpienia ostatecznie bowiem kieruje podmiot liryczny ku Bogu, nadrzędnej sile rządzącej światem. Optymistyczny ton wiersza wieńczącego cykl Morelowskiego ma jednak w dużej mierze charakter kompensacyjny i życzeniowy, co sprawia, że ogólna wymowa Trenów traci na jednoznaczności, tym bardziej eksponując tragizm doświadczeń podmiotu (zarówno w wariancie jednostkowym, jak i ewokowanym kontekstem - zbiorowym).

Sygnalizowane tu poczucie zagubienia oraz doznanie uraty jest częstym motywem poezji porozbiorowej. Rozziew między potęgą I Rzeczypospolitej i wolnością, jaką cieszyli się jej obywatele a kondycją zesłańca-tułacza jest widoczny nie tylko w (przywoływanych już jako kontekst do cyklu Morelowskiego) wierszach Juliana Ursyna Niemcewicza i Hugona Kołłątaja. W Muzie polskiej pod tytułem: Pieśni osiemdziesięcioletniego starca Jędrzeja Świderskiego, legionisty, napoleońskiego oficera i poety, tytułowy bohater, wspominając własną minioną młodość, snuje refleksje nad przemijalnością. Stają się one okazją do rozważań dotyczących kondycji jego rodaków - niegdyś dumnych i wolnych obywateli, teraz żołnierzy przymusowo wcielanych do wrogich sobie armii, 
rozproszonych po całym świecie ${ }^{47}$. Kwestie te podejmuje też Świderski m.in. w wierszu Walka filozofa z losem czy w cyklu pt. Dumania Wenety nad ojczyzna, które stały się przedmiotem analizy Romana Dąbrowskiego ${ }^{48}$. Warto również wspomnieć twórczość Cypriana Godebskiego, zwłaszcza zaś Wiersz do Legiów polskich i powieść pt. Grenadier-filozof. Powieść prawdziwa. Wyjęta z dziennika podróży roku 1799, w dużej mierze opartej na doświadczeniach samego autora ${ }^{49}$.

Wspomniane utwory - podobnie jak omawiane Treny - warto czytać przez pryzmat zagadnień związanych $\mathrm{z}$ autoekspresją, zwłaszcza zaś w kontekście sposobów konstytuowania „Ja”, co może rzucić nieco światła na poezję dotychczas interpretowaną głównie przez pryzmat wydarzeń politycznych oraz (często mylącej) kategorii tzw. przełomu romantycznego, wielokrotnie przesłaniających silne i wyraziste związki między oświeceniem a romantyzmem ${ }^{50}$. Wydaje się również, że wskazane na przykładzie utworu Morelowskiego środki literackiego obrazowania, służące wyeksponowaniu kondycji podmiotu lirycznego, skłaniają do rewizji dotychczasowych ocen cyklu, którego, jak można mniemać, rzekome „braki” wynikały z przyjętej przez wielu badaczy perspektywy romantycznej.

\section{Bibliografia:}

Brzozowski J., Muzy w poezji polskiej: dzieje toposu do przełomu romantycznego, Wrocław 1986.

Budzyński J., Horacjanizm w liryce polsko-łacińskiej renesansu i baroku, Wrocław 1985.

Cieński M., Karpiński wobec doświadczenia wygnania: biografia i kreacja literacka, [w:] tegoż, Literatura polskiego oświecenia wobec tradycji i Europy, Kraków 2013, s. 161 - 172.

Dubisz S., Modlitewno-religijne incipity utworów wierszowanych okresu konfederacji barskiej, „Poradnik Językowy" 1996, z. 9, s. 41 - 47.

Dziechcińska H., Sztuka przekonywania w kulturze polskiej trzech stuleci: XVI - XVII - XVIII wiek, Warszawa 2010.

Eustachiewicz M., "Psalmodia polska” W. Kochowskiego na tle staropolskich stylizacji biblijnych, „Pamiętnik Literacki” 1974, z. 2, s. 45 - 78.

Falińska M., Przeszłość a teraźniejszość. Studium z dziejów świadomości historycznej społeczeństwa staropolskiego, Warszawa 1986.

Florczak Z., Europejskie źródła teorii językowych w Polsce na przełomie XVIII i XIX wieku. Studia z dziejów teorii języka i gramatyki, Wrocław 1978.

47 J. Świderski, Utwory poetyckie. Antologia, wybór, opr., wstęp R. Dąbrowski, Kraków 2010, s. 119.

48 R. Dąbrowski, Doświadczenia żołnierza-patrioty w twórczości Jędrzeja Świderskiego, w: Emigranci, wygnańcy, wychodźcy..., dz. cyt., s. 71-89.

49 Monografię Cyprianowi Godebskiemu poświęcił Artur Timofiejew, Legiony i vitae lex. Problemy twórczości literackiej Cypriana Godebskiego, Lublin 2002. Kwestię legionowej tułaczki, stematyzowanej przez Godebskiego, podjął też Bogusław Dopart, Pochwała „Grenadiera-filozofa Cypriana Godebskiego, w: Emigranci, wygnańcy, wychodźcy..., dz. cyt., s. 37-47.

$50 \mathrm{O}$ owych związkach wspominali m.in., M. H. Abrams, Zwierciadło i lampa: romantyczna teoria poezji a tradycja krytycznoliteracka, przeł. M. B. Fedewicz, Gdańsk 2003, M. Stanisz, Wczesnoromantyczne spory o poezję, Kraków 1998; J. Płuciennik, Nowożytny indywidualizm a literatura. Wokół hipotez o kreacyjności Edwarda Younga, Kraków 2006. 
Grabowska D., Twórczość kałuska Wacława Rzewuskiego, „Zeszyty Naukowe Wydziału Humanistycznego Uniwersytetu Gdańskiego. Prace Historycznoliterackie" 1985, z. 8-9, s. 21-36.

Gruchała J., „Psalmy, hymny, Pieśnie pełne ducha." Studia o staropolskich tekstach religijnych, Kraków 2013.

Grześkowiak-Krwawicz A., Regina libertas. Wolność w polskiej myśli politycznej XVIII wieku, Gdańsk 2006.

Kostkiewiczowa T., Inspiracje psałterzowe wyobraźni poetyckiej epok dawnych (rekonesans), w: Księga psalmów. Modlitwa, przekład, inspiracja, pod red. P. Mitznera, Warszawa 2007, s. 85 - 103.

Lasocińska E., „Cnota sama z mądrościa jest naszym żywotem”. Stoickie pojęcie cnoty w poezji polskiej XVII wieku, Warszawa 2003.

Morelowski J., Treny i Sen, wstęp St. z Kutnego, Kraków 1910.

Morelowski J., Wiersze Józefa Morelowskiego, wstęp E. Aleksandrowska, Wrocław 1983

Pelc J., Obraz - słowo - znak. Studium o emblematach w literaturze staropolskiej, Wrocław 1973.

Pelc J., Tren, w: Słownik Literatury Staropolskiej, pod red. T. Michałowskiej, Wrocław 1990, s. $874-877$.

Ricouer P., Skarga jako modlitwa, w: A. LaCocque, tegoż, Myśleć biblijnie, przeł. E. Mukoid, M. Tarnowska, Kraków 2003, s. 286 - 306.

Sokolski J., Bogini, pojęcie, demon. Fortuna w dziełach autorów staropolskich, Wrocław 1996.

Włoch W., Polska elegia patriotyczna w epoce rozbiorów, Kraków 1916.

Woronicz J. P., Pisma wybrane, wstęp i oprac. M. Nesteruk, Z. Rejman, Warszawa 1993.

Zielaskowska E., O rymotwórstwie i rymotwórcach. Ignacy Krasicki między starożytnikami i nowożytnikami, Poznań 2014.

Żbikowski P., „...bolem śmiertelnym ściśnione mam serce... Rozpacz oświeconych u źródeł romantycznego przełomu w poezji polskiej w latach 1793-1805. Wrocław 1998.

Żbikowski P., Klasycyzm postanisławowski. Doktryna estetycznoliteracka, Warszawa 1984

\section{Streszczenie:}

Głównym celem artykułu jest lektura Trenów Józefa Morelowskiego jako utworu wyrażającego kryzys podmiotu. Autorka rozprawy proponuje, by cykl wierszy, powstałych po upadku Rzeczypospolitej, ująć w kontekście tradycji antycznej i staropolskiej. Daje to szansę na dostrzeżenie i wyeksponowanie różnorodnych sposobów manifestowania „Ja" w tekście poetyckim. Wydaje się bowiem, że uruchomienie zakorzenionych w kulturze literackiej toposów i środków literackiego obrazowania jest próbą przezwyciężenia kryzysu i dezintegracji podmiotu. Ponadto, zwrócenie uwagi na wpływ tradycji i literackiej konwencji pozwala zrewidować stan badań i przemyśleć dotychczas poczynione obserwacje o charakterze tzw. przełomu romantycznego.

Słowa klucze: treny, oświecenie, poezja, „Ja.”

\section{The condition of the subject in view of the partition of Poland. Józef Morelowski's Laments}

\section{Summary:}

The main aim of the article is a reading of Józef Morelowski's Laments as a text which expresses the crisis of the subject. The author of the article proposes a an interpretation of this cycle of poems, written after the Third Partition of Poland, in the context of the antique and Old Polish tradition. It gives an opportunity to show and to emphasize diverse ways of self-manifestation in the poetical works. It appears that using literary topoi and stylistic devices rooted in culture is an attempt to 
overcome the crisis of the subject. Furthermore, taking into consideration the role of tradition and literary convention might help us to reconsider the state of research and to rethink conclusions, which have been reached so far, about the so-called romantic breakthrough.

Keywords: laments, enlightenment, poetry, "Self”. 